\title{
Primary Screening Of Phytochemicals Present In Crude Extracts Of Leaf, Stem And Rhizome Of Costus Igneus (Insulin Plant)
}

\author{
Damam Malleswari $^{1}$, Rana Kausar ${ }^{2}$, Gaddam Bagyanarayana ${ }^{3}$ \\ Applied Mycology and Plant Pathology Laboratory, Department of Botany, Osmania University, Hyderabad, \\ Telangana, India.Email: malleswari.d@ gmail.com
}

\begin{abstract}
Phytochemicals are secondary metabolites produced by all plants, some of which are of great medicinal value. Primary screening of phytochemicals is a crucial step in the detection of the bioactive compounds present in medicinal plants, and consequently may lead to drug discovery and development. Qualitative analysis was done to investigate the active phytoconstituents present in Costus igneus. In the present study, leaf, stem and rhizome extracts were prepared with different solvents, viz. ethanol, methanol, acetone, ethyl acetate and chloroform. A total number of 19 phytochemicals, viz. alkaloids, cardiac glycosides, flavonoids, saponins, tannins, terpenoids, anthraquinones, reducing sugars, glycosides, phlobatannins, organic acids, proteins, amino acids, steroids, carbohydrates, oils \& resins, phenols, carboxylic acid and quinones were tested for their presence or absence in the different parts of the plant. Ethanol and methanol proved to be better solvents than others, as the crude extracts showed the presence of more number of phytochemicals like, flavonoids, alkaloids, anthraquinones, taninns, phenolic compounds, terpenoids, saponins, carbohydrates and proteins etc. Other solvents showed the presence of fewer phytochemicals. Leaves and rhizome were found to contain more phytochemicals when compared to stem. These phytochemicals will be of great value in the herbal drug industry.
\end{abstract}

Key words: Costus igneus, Phytochemicals, Leaf, Stem, Rhizome extracts.

\section{INTRODUCTION}

Medicinal plants play a convincing role in the prevention and treatment of several diseases. They can be a reservoir of chemical compounds of biological and pharmacological importance. Costus igneus also known as fiery costus or spiral flag or insulin plant contains a range of phytochemicals viz flavonoids, alkaloids, terpenoids and it is traditionally used in India to control diabetes. [1, 2, 3, 4]. Costus igneus (Insulin plant) is one of the folk medicines used for the treatment for Diabetes mellitus. This plant belongs to Costaceae family, which has been separated from Zingiberaceae on the basis of the presence of spirally arranged leaves and rhizomes being free from aromatic essential oils [5]

A recent study has shown that the leaves of insulin plant (Costus igneus) reduced the fasting and postprandial blood sugar levels, bringing them down to normal, in dexamethasone-induced hyperglycemia 


\section{Available online at www.ijrat.org}

in rats. Reduction in the fasting and the postprandial blood sugar levels with leaves of insulin plant was comparable with that obtained with Glibenclamide $500 \mu \mathrm{g} / \mathrm{kg}$ at $250 \mathrm{mg} / \mathrm{kg} / \mathrm{day}$ and $500 \mathrm{mg} / \mathrm{kg} / \mathrm{day}$ of powdered leaves of the insulin plant (Costus igneus). [6]

Recently, a number of researches have been carried out to evaluate the anti-diabetic potential of this plant. Besides, it has been proven to possess various pharmacological activities like hypolipidemic, diuretic, antioxidant, anti-microbial, and anticancerous. Further, various phytochemical investigations reveal the presence of carbohydrates, triterpenoids, proteins, alkaloids, tannins, saponins, flavonoids, steroid, and appreciable amounts of trace elements. [7].

The present study was taken up to estimate and compare the important phytoconstituents present in leaves, stem and rhizomes of C.igneus.

\section{MATERIALS AND METHODS}

\subsection{Collection and Drying of plant materials:}

Healthy C.igenus plant were collected from the Botanical garden, Department of Botany, Osmania University, Hyderabad, Telangana. The leaves, stem and rhizome of Costus igenus were separated and washed thoroughly three times with water and once with distilled water. The plant material was air-dried for 15 to 21 days, and ground to fine powder in a grinder. The powdered samples were sealed in separate polythene bags until the time of extraction.

\subsection{Preparation of plant extract with different} solvents: $10 \mathrm{gm}$ of leaf, stem and rhizome powder was added to $150 \mathrm{ml}$ of different solvents like ethanol, methanol, acetone, ethyl acetate and chloroform and stirred constantly for 48 hours on orbital shaker. The extracts were then filtered using Whatman filter paper No.3. The filtrate was then stored at $4^{\circ} \mathrm{C}$ until use.

2.3. Chemicals used: The chemicals used were of analytical grade. Chemicals such as Wagner's reagent, chloroform, $2 \% \quad \mathrm{H}_{2} \mathrm{SO}_{4}$, conc. $\mathrm{H}_{2} \mathrm{SO}_{4}, 10 \%$ lead acetate, Benedicts reagent, $0.1 \% \mathrm{FeCl}_{3}$, Fehlings solution, dilute $\mathrm{NaOH}, 2 \% \mathrm{HCl}, 10 \%$ ammonia, $10 \%$ $\mathrm{HCl}$ were prepared. Different solvents like ethanol, methanol, acetone, ethyl acetate and chloroform were used for extraction.

\subsection{Preparation of solutions:}

2.4.1. Fehling's solution: A mixture of equal volume of copper sulphate, sodium potassium tartarate and sodium hydroxide was prepared.

2.4.2. Wagner's Reagent: $2 \mathrm{gm}$ of Iodine and $6 \mathrm{gm}$ of potassium iodide were mixed in $100 \mathrm{ml}$ of water.

\subsection{Preliminary Qualitative Phytochemical Analysis:}

Preliminary phytochemical screening was carried out to identify the secondary metabolites present in the various extracts of leaves, stem and rhizome of $C$. igneus with the standard methods [8].

(1) Alkaloids: To $2 \mathrm{ml}$ of extract, $2 \mathrm{ml}$ of Wagner's reagent was added. The appearance of a brownish precipitate indicates the presence of alkaloids.

(2) Cardiac glycosides: $2 \mathrm{ml}$ of extract was mixed with $2 \mathrm{ml}$ of chloroform and conc. $\mathrm{H}_{2} \mathrm{SO}_{4}$ was carefully added to form a layer. Deep reddish-brown colour at the inter face of steroid ring indicates the presence of cardiac glycosides. 


\section{E-ISSN : 2321-9637 \\ Available online at www.ijrat.org}

(3) Flavonoids: To $2 \mathrm{ml}$ of extract, $2 \mathrm{ml}$ of $10 \%$ lead acetate was added. Yellowish-green colour indicates the presence of flavonoids.

(4) Saponins: To $2 \mathrm{ml}$ of extract, $2 \mathrm{ml}$ of Benedicts reagent was added. Bluish-black precipitate indicates the presence of saponins.

(5) Tanins: To $2 \mathrm{ml}$ of extract, $0.1 \%$ ferric chloride was added. Brownish-green colour indicates the presence of tannins.

(6) Terpenoids: To $2 \mathrm{ml}$ of extract, $2 \mathrm{ml}$ of chloroform and conc. $\mathrm{H}_{2} \mathrm{SO}_{4}$ was carefully added to form a layer. A reddish-brown colour indicates the presence of terpenoids.

(7) Anthraquinones: $1 \mathrm{ml}$ of extract was boiled with $10 \% \mathrm{HCl}$ for few minutes in a water bath, then filtered and allowed to cool. Equal volume of $\mathrm{CHC}_{3}$ and few drops of $10 \%$ Ammonia was added to the mixture and heated. Appearance of rose-pink colour indicates the presence of anthraquinones.

(8) Reducing sugars: The extract was shaken with distilled water and filtered. The filterate was boiled with Fehlings solution A and B for few minutes. An orange-red precipitate indicates the presence of reducing sugars.

(9) Glycosides: The extract was hydrolysed with $\mathrm{HCl}$ solution and neutralized with $\mathrm{NaOH}$ solution. A few drops of Fehlings solution A and B were added. Red precipitate indicates the presence of glycosides.

(10) Phlobatanins: The extract was dissolved in distilled water and filtered. The filterate was boiled with $2 \%$ HCL solution. Red precipitate shows the presence of phlobatanins.

(11) Organic acids: Few drops of $\mathrm{CaCl}_{2}$ were added to the $5 \mathrm{ml}$ of leaf extract. Immediate precipitation indicates the presence of organic acids.
(12) Proteins: The extract was treated with $\mathrm{CuSO}_{4}$ solution. Formation of a violet color complex indicated the presence of proteins.

(13) Amino acids: To $0.5 \mathrm{ml}$ of extract two drops of freshly prepared $0.2 \%$ Ninhydrin reagent was added and heated. The appearance of pink or purple colour indicates the presence of peptides or amino acids.

(14) Steroids: To $2 \mathrm{ml}$ of solvent extract, $2 \mathrm{ml}$ of chloroform and $2 \mathrm{ml}$ of conc. $\mathrm{H}_{2} \mathrm{SO}_{4}$ was added slowly and shaken well. The chloroform layer turned red and sulphuric acid layer turned greenish yellow, which indicated the presence of sterols.

(15) Detection of Oils and Resins: Test solution was applied on filter paper. Transparent appearance on the filter paper indicates the presence of oils and resins.

(16). Carbohydrates: A few drops of Molisch reagent were added to the extract followed by conc. $\mathrm{H}_{2} \mathrm{SO}_{4}$. The formation of a violet ring at the junction of two liquids indicates the presence of carbohydrates.

(17) Phenols: To $1 \mathrm{ml}$ of extract, $2 \mathrm{ml}$ of distilled water and a few drops of $10 \%$ aqueous ferric chloride solution were added. Formation of blue or green colour indicates the presence of phenols.

(18) Carboxylic acid: One $\mathrm{ml}$ of the extracts was treated with a few $\mathrm{ml}$ of sodium bicarbonate solution. Effervescence (due to liberation of carbon dioxide) indicates the presence of carboxylic acid.

(19) Quinones: One $\mathrm{ml}$ of extract was treated with alcoholic KOH solution. Quinones give coloration ranging from red to blue. 
E-ISSN: 2321-9637

\section{Available online at www.ijrat.org}

\section{RESULTS AND DISCUSSION}

The emergence of diabetes-related disorders and the undesirable side-effects of currently used antidiabetic drugs have motivated researchers in recent times to identify and investigate new alternative drugs from natural resources. Qualitative analysis was performed to investigate the active phytoconstituents of Costus igneus.

Leaf, stem and rhizome of Costus igneus were extracted with different solvent such as ethanol, methanol, acetone, ethyl acetate and chloroform. A total 19 phytochemicals such as alkaloids, cardiac glycosides, flavonoids, saponins, tannins, terpenoids, anthraquinones, reducing sugars, glycosides, phlobatannins, organic acids, proteins, amino acids, steroids, carbohydrates, oils \& resins, phenols, carboxylic acid and quinones were tested for their presence/absence in the different parts of the plant.

Among the different solvents used, ethanol and methanol extracts showed the presence of all the 19 phtochemicals such as alkaloids, cardiac glycosides, flavonoids, saponins, tannins, terpenoids, anthraquinones, reducing sugars, glycosides, phlobatannins, organic acids, proteins, amino acids, steroids, phenols, carboxylic acid and quinones except oils and resins. The findings reveal the presence of various bioactive secondary metabolites which might be responsible for the medicinal property of these plants. The observations are presented in Table 1.

With the acetone, ethyl acetate and chloroform solvents, the presence/absence of various compounds varied significantly (Table 1). Presence of saponins, alkaloids, flavonoids, tannins, proteins, amino acids, sterols were observed in acetone extracts, while other compounds were absent. Alkaloids, tannins, amino acids were found to be present in ethyl acetate extract, while other phytoconstituents were absent. Chloroform extract showed the presence of only alkaloids, flavonoids, saponins and reducing sugars. Oils and resins were absent in all the solvent extracts. Secondary metabolites contribute towards the bioactivities of medicinal plants such as hypoglycemic, antioxidant, anti-inflammatory and anti-carcinogenic properties [9].

C. igneus has traditionally been used in the treatment of hyperglycemia. The medicinal role of these plants could be related to the presence of bioactive compounds as identified in the present study.

Table1. Phytochemical analysis of leaf, stem and rhizome extracts of Costus igneus

\begin{tabular}{|c|c|c|c|c|c|c|c|}
\hline & Phytochemicals & & $\begin{array}{l}\text { Ethanol } \\
\text { extract }\end{array}$ & $\begin{array}{c}\text { Methanol } \\
\text { extract }\end{array}$ & $\begin{array}{c}\text { Acetone } \\
\text { extract }\end{array}$ & $\begin{array}{c}\text { Ethylacetate } \\
\text { extract }\end{array}$ & $\begin{array}{c}\text { Chloroform } \\
\text { extract }\end{array}$ \\
\hline \multirow[t]{3}{*}{1} & \multirow[t]{3}{*}{ Alkaloids } & $\mathrm{L}$ & + & - & - & - & - \\
\hline & & $\mathrm{S}$ & + & + & + & + & + \\
\hline & & $\mathrm{R}$ & + & + & + & + & + \\
\hline \multirow[t]{3}{*}{2} & \multirow[t]{3}{*}{ Cardiac glycosides } & $\mathrm{L}$ & + & - & - & - & - \\
\hline & & $\mathrm{S}$ & + & - & - & - & - \\
\hline & & $\mathrm{R}$ & + & + & - & - & - \\
\hline \multirow[t]{3}{*}{3} & \multirow[t]{3}{*}{ Flavonoids } & $\mathrm{L}$ & + & + & + & - & + \\
\hline & & $\mathrm{S}$ & + & + & - & - & - \\
\hline & & $\mathrm{R}$ & + & - & - & - & - \\
\hline \multirow[t]{2}{*}{4} & \multirow[t]{2}{*}{ Saponins } & $\mathrm{L}$ & + & - & + & - & + \\
\hline & & $\mathrm{S}$ & + & - & + & - & + \\
\hline
\end{tabular}


International Journal of Research in Advent Technology, Vol.7, No.3, March 2019

E-ISSN: 2321-9637

\section{Available online at www.ijrat.org}

\begin{tabular}{|c|c|c|c|c|c|c|c|}
\hline & & $\mathrm{R}$ & + & - & + & - & + \\
\hline \multirow[t]{3}{*}{5} & \multirow[t]{3}{*}{ Tannins } & $\mathrm{L}$ & + & + & - & + & - \\
\hline & & $\mathrm{S}$ & + & + & + & - & - \\
\hline & & $\mathrm{R}$ & + & + & + & - & - \\
\hline \multirow[t]{3}{*}{6} & \multirow[t]{3}{*}{ Terpenoids } & $\mathrm{L}$ & + & - & - & - & - \\
\hline & & $\mathrm{S}$ & + & + & - & - & - \\
\hline & & $\mathrm{R}$ & + & + & - & - & - \\
\hline \multirow[t]{3}{*}{7} & \multirow[t]{3}{*}{ Anthraquinones } & $\mathrm{L}$ & + & - & - & - & - \\
\hline & & $\mathrm{S}$ & - & - & - & - & - \\
\hline & & $\mathrm{R}$ & + & + & - & - & - \\
\hline \multirow[t]{3}{*}{8} & \multirow[t]{3}{*}{ Reducing sugars } & $\mathrm{L}$ & - & - & - & - & + \\
\hline & & $\mathrm{S}$ & - & - & - & - & + \\
\hline & & $\mathrm{R}$ & + & + & - & - & + \\
\hline \multirow[t]{3}{*}{9} & \multirow[t]{3}{*}{ Glycosides } & $\mathrm{L}$ & + & + & - & - & - \\
\hline & & $\mathrm{S}$ & - & - & - & - & - \\
\hline & & $\mathrm{R}$ & + & + & - & - & - \\
\hline \multirow[t]{3}{*}{10} & \multirow[t]{3}{*}{ Phlobatanins } & $\mathrm{L}$ & + & + & - & - & - \\
\hline & & $\mathrm{S}$ & + & + & - & - & - \\
\hline & & $\mathrm{R}$ & + & - & - & - & - \\
\hline \multirow[t]{3}{*}{11} & \multirow[t]{3}{*}{ Organic acids } & $\mathrm{L}$ & + & + & - & - & - \\
\hline & & $\mathrm{S}$ & + & + & - & - & - \\
\hline & & $\mathrm{R}$ & + & - & - & - & - \\
\hline \multirow[t]{3}{*}{12} & \multirow[t]{3}{*}{ Proteins } & $\mathrm{L}$ & + & + & + & - & - \\
\hline & & $\mathrm{S}$ & - & - & - & - & - \\
\hline & & $\mathrm{R}$ & + & + & - & - & - \\
\hline \multirow[t]{3}{*}{13} & \multirow[t]{3}{*}{ Amino acids } & $\mathrm{L}$ & + & + & + & + & - \\
\hline & & $\mathrm{S}$ & + & + & + & - & - \\
\hline & & $\mathrm{R}$ & + & + & + & - & - \\
\hline \multirow{3}{*}{14} & \multirow{3}{*}{ Steroids } & $\mathrm{L}$ & + & + & + & - & - \\
\hline & & $\mathrm{S}$ & - & - & - & - & - \\
\hline & & $\mathrm{R}$ & - & - & - & - & - \\
\hline \multirow[t]{3}{*}{15} & \multirow[t]{3}{*}{ Carbohydrates } & $\mathrm{L}$ & + & + & - & + & - \\
\hline & & $\mathrm{S}$ & - & - & - & - & - \\
\hline & & $\mathrm{R}$ & + & + & - & - & - \\
\hline 16 & Oils and Resins & $\mathrm{L}$ & - & - & - & - & - \\
\hline & & $\mathrm{S}$ & - & - & - & - & - \\
\hline & & $\mathrm{R}$ & - & - & - & - & - \\
\hline 17 & Phenols & $\mathrm{L}$ & + & - & - & - & - \\
\hline & & $\mathrm{S}$ & + & - & - & - & - \\
\hline & & $\mathrm{R}$ & + & - & - & - & - \\
\hline 18 & Carboxylic acid & $\mathrm{L}$ & + & + & - & - & - \\
\hline & & $\mathrm{S}$ & + & - & - & - & - \\
\hline & & $\mathrm{R}$ & + & + & - & - & - \\
\hline 19 & Quinones & $\mathrm{L}$ & + & + & - & - & - \\
\hline & & $\mathrm{S}$ & - & + & - & - & - \\
\hline & & $\mathrm{R}$ & - & + & - & - & - \\
\hline
\end{tabular}

Note: L=Leaf, $\mathrm{S}=$ Stem, $\mathrm{R}=$ Rhizome; + = Present, - = Absent 


\author{
E-ISSN : 2321-9637 \\ Available online at www.ijrat.org
}

\section{CONCLUSION}

Qualitative analysis was done to investigate the active phytoconstituents present in Costus igneus. Of the different solvents used in preparing the extracts, ethanol and methanol proved to be better solvents than others, as the crude extracts showed the presence of more number of phytochemicals like, flavonoids, alkaloids, anthraquinones, taninns, phenolic compounds, terpenoids, saponins, carbohydrates and proteins etc. Other solvents showed the presence of fewer phytochemicals. Leaves and rhizome were found to contain more phytochemicals when compared to stem.

Further research and efforts to utilize the phytochemicals present in Costus igneus, in the treatment of diabetes and other disorders, would be of great significance in the herbal drug industry, and thereby in human welfare.

\section{ACKNOWLEDGEMENTS}

Dr. Damam Malleswari is very grateful to the University Grants Commission (UGC), New Delhi for providing fellowship under Post Doctoral Fellowship for Women for the year 2012-13 with grant No. F.15- 1/2012-13/PDFWM-2012-13-OBAND-18863 (SA-II) and The Head, Dept. of Botany, Osmania University for the physical facilities.

\section{REFERENCES}

[1] Devi, VD.; Urooj, A. (2008): Hypoglycemic potential of Morus indica $\mathrm{L}$ and Costus igneus Nak A preliminary study. Indian Journal of Experimental Biology. 46(8), pp. 614-616.

[2] Saraswathi, R.; Upadhyay, L.; Venkatakrishnan,

R.; Meera, R.; Devi, P. (2010): Isolation and biological evaluation of steroid from stem of Costus igneus. Journal of Chemical Pharmaceutical Research. 2, pp. 444-8.

[3] Bhat, V.; Asuti, N.; Kamat, A.; Sikarwar, MS.; Patil, MB. (2010): Antidiabetic activity of insulin plant (Costus igneus) leaf extract in diabetic rats. Journal of Pharmaceutical Research. 3, pp. 608-11. [4] Shetty, AJ.; Parampalli, SM.; Bhandarkar, R.; Kotian, S. (2010): Effect of the insulin plant (Costus igneus) leaves on blood glucose levels in diabetic patients: A cross sectional study. Journal of Clinical Diagnostic Research. 4, pp. 2617-21.

[5] Jose, B., Reddy, LJ. (2010): Analysis of the essential oils of the stems, leaves and rhizome of the medicinal plant Costus pictus from southern India. International Journal of Pharmacy and Pharmaceutical Sciences. 2 (2), pp. 100-1.

[6] Saravanan, A.; Karunakaran, S.; Vivek, P.; Dhanasekaran, S. (2014): Studies on antibacterial activity of root extract of Costus igneus. International Journal of Chemical and Technology Research. 6, pp. $4201-4206$

[7] Devi, VD.; Urooj, A. (2010): Nutrient profile and antioxidant components of Costus speciosus Sm. and Costus igneus Nak. Indian Journal of Natural Product Resources. 1(1), pp. 116-118.

[8] Harborne, JB. (1973): Phytochemical methods, London.Chapman and Hall, Ltd. London: U.K., pp. 49-188.

[9] Negi, JS.; Singh, P.; Rawat, B. (2011): Chemical constituents and biological importance of Swertia: a review. Current Research in Chemistry. 3(1), pp. 1-5. 